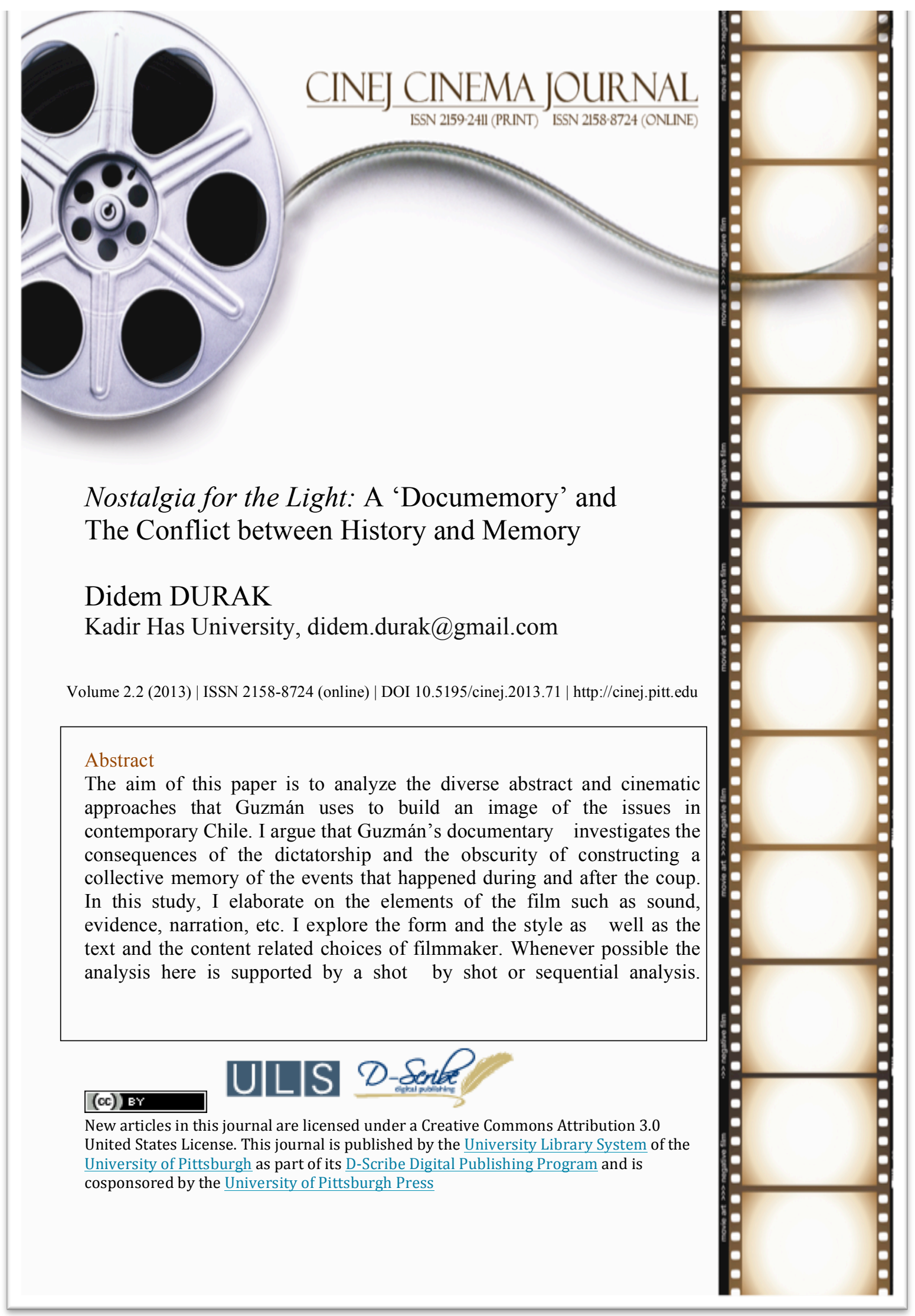




\section{Nostalgia for the Light: A 'Documemory' and The Conflict between History and Memory}

\section{Introduction}

Life and death, joy and pain, hope and despair... Patricio Guzmán's Nostalgia for the Light is a manifestation of several paradoxes. Nevertheless it is also a documentary regarding time, longing and memory where evidence meets memory and science meets anticipation.

The aim of this paper is to analyze the diverse abstract and cinematic approaches that Guzmán uses to build an image of the issues in contemporary Chile. I argue that Guzmán's documentary investigates the consequences of the dictatorship and the obscurity of constructing a collective memory of the events that happened during and after the coup. In this study, I elaborate on the elements of the film such as sound, evidence, narration, etc. I explore the form and the style as well as the text and the content related choices of filmmaker. Whenever possible the analysis here is supported by a shot by shot or sequential analysis.

\section{The Title: A Promise That Was Not Kept}

Just like the original title of the movie Nostalgia de La Luz translates both into Nostalgia for the Light and Nostalgia of the Light, Guzmán's Nostalgia for the Light is a cinematic journey that is the product of a desire to come to terms with social history. The documentary does not claim absolute truth about forgetting and not forgetting. And yet it promises a total experience of nostalgia. The film reminded me of the Portuguese word "saudade" which has no immediate translation in English. Although it can be described as the strong nostalgic longing for an absent person or object. Nostalgia for the Light is like a saudade for the light, serenity, and the victory of human rights. The observatory was the outcome of a promise to make the Chilean astronomy prosper. A promise that was never kept... The scientific hope for light was interrupted with the violent activities of the Pinochet regime.

\section{The Main Premises: Time, Loss, and Hope}

Nostalgia for the Light invites us to believe as much as we have roots under our feet, we also have roots up in the sky. It is a poetical movie working with metaphors and analogisms to demonstrate that the past is important.

Guzmán's choice of Atacama Desert is not by chance. The desert is at the very core of the story. It serves as the starting point of the argument of the film and the base for the contrasts. As the driest place on earth and the Atacama Desert is a perfect place for astronomers since the sky is translucent there, and also a perfect place for archaeologists because the salt and the lack of humidity mummifies the bodies and preserves some materials. The desert is the connection between the past and the present, and the darkness and the light. Even though the desert is such a great place for scientists, it is very sad that with a perfect access to the past, Chile 
cannot still reveal the truth about its grievous past. The major argument here is that we should be at peace with the past, analyze it and have a better future without the haunting or the interruption of the past.

Guzmán is aware that we cannot escape from the past and the Atacama Desert is a wonderful to demonstrate this fact. And yet how much of the past should we remember? Should we allow it to interfere with our presence? The director knows the answer to these questions, and emphasizes that if Chile succeeds in constructing a social history from the personal memories, and the evidence that should be provided by the military and the politicians, the relatives of the victims will find peace. Grief and happiness can exist together. Sometimes one follows the other. The darkness of the night bring the stars, the resolution to the traumas of a dark past can bring optimism and light. The nostalgia does not have to be forever. Violence is not the only element of the past that keeps recurring.

\section{The Opening Sequence: Origins, Cycle, La Belle Époque}

The film starts with the noisy old German telescope ALMA (the Atacama Large Millimeter/Sub millimeter Array, also meaning 'soul' in Spanish) and the observatory. The gears rotate, and the camera approaches the telescope and circles around it giving us the feeling that we are following its movements too. Every move of the parts of the telescope is so delicate that you would not expect from such a gigantic and old machine. With these images of gears rotating slowly, we undergo a relative feeling of time: the time in these scenes, even watching them for several times, moves slowly. The moving and circling around also remind us of the galaxy and the motion of the Earth around the Sun. We are left with the feelings of the present only. This scene is followed by the footage Moon and the craters as if we are looking through the telescope. The images are almost hypnotizing. Guzmán takes his time before he transfers us to a more intimate atmosphere. He seems to make sure that we are ready for the following scenes or maybe the ones following them. The stunning images of the space symbolize the quest for the origins of the mankind in addition to the cycle of life.

After the images of the moon, the camera wanders along some objects which represent the director's childhood and provincial life - also the past that cannot be destroyed by a puff of air. When the leaves sway in the wind, we look through kitchen window. Guzmán assists us in relating ourselves to him, and to warm up. Objects represent the truth, the reality and objectivity. Until now, the voiceover commentary does not commence. We only hear a very serene music. The objects we are shown such as the old sewing machine and the folded napkin could probably be found in many houses during that time in many countries. The window with the curtains resists to time. We may infer and come up with our interpretations of the scenes up until now but we are not likely to draw to any conclusions yet. Even though in the beginning we do not know what the movie will be about (the space or childhood or nostalgia, we do not know) we can somehow guess that it will not be a personal story. It will not be about Guzmán's 
childhood and his love for astronomy. His words do not reveal his personal story but rather the collective memory in Chile.

The house is typical however we feel that the movie will be atypical in many senses. The use of objects at this point foresees that the filmmaker will use either direct or metaphoric representations throughout the whole movie.

In this sequence Guzmán speaks about the Chile in his childhood in the voiceover commentary. We do not see his presence. (Actually we do not meet any of the people in the documentary until the $14^{\text {th }}$ minute of the documentary.) He says his passion for astronomy started in Santiago with ALMA.

Guzmán tells in a very tranquil voice:

Chile was a haven of peace, isolated from the world. Santiago slept in the foothills of the Cordillera, detached from the rest of the world... Nothing ever happened. The Presidents of the Republic walked through the streets unescorted. Only the present moment existed.' Nothing ever happened (nunca ocurría nada) and only the present moment existed (solo el presente existía).

The life was peaceful... These words which resemble a poem inform us that in the upcoming minutes of the documentary there will not be only the peaceful present moment. The present that expects us will be a present composite of prior experiences. The camera shifts to a street where two houses (one looks old the other new, one representing the past the other the present) and tree situated in the middle of them. This image is overlapped with the swirling dust particles. This might be a symbol of the past overlapping with the present. Each present becomes a past, and each past was a present at some time.

Guzmán says this peaceful life came to an end after the coup and he feels lucky to be a part of it: "Time of hope forever engraved in my soul." From his words we learn that this is the time science got interested in Chile. Sometime later the coup erased everything, including science. Here is a small but quite important detail. Guzmán's continues to narrate. The science in Chile has also suffered from the coup. This fact makes it easier for us to connect astronomy and politics (and memory) throughout the whole movie. Here the camera shows us some old parts of machines and tools used for astronomy that seem to be broken or no longer used. (Yet another moment in the movie where Guzmán uses representative objects to support his point).

There is a dissolve to the tranquil swirling particles of dust only. It is almost magical. We still cannot guess that these beautiful images of the dust or the observatory or the sky will lead to a story that has so many poignant sides to it. We do not need to worry. Guzmán knows how to balance all the contrasts. The peace was long gone after the coup.

Guzmán does not support the information about the coup with archival footage, interviews with the politicians or the stills that show us the coup. His way is not 
observational. Instead, we are shown the huge vastness of the galaxy. There is the wind and the vastness only. Even in this scene the viewer is reminded that the present is shaped by the past because the dust particles are the particles from the past, from the stars, from the bones or from our old homes.

\section{Science: Astronomy and Archaeology}

We see the Atacama Desert from the space. Then we see a closer image of it. Then another closer one, and finally we feel as if we walk on it as the camera meanders on the salty and dry ground of the desert. We walk slowly with the camera, and see the ground in detail where we hear Guzmán comparing the ground of the desert with that of Mars. He says there is nothing but yet it is full of history. The next minutes are full of faster still images of the desert and its surrounding and the objects are frozen in time. Then we see the telescopes from different angles. After a guy with white hair (probably Guzmán himself) enters one of these telescopes there is a shift to the images of galaxy. We share the joy of observing the space and the stars also watch us from above. One moment it is the image shiny stars, the next moment it is the image of the vast galaxy with desert like spots, and the next moment we see the stars shining again. Then we see the domes of the observatory at night. Has time passed while we were watching the stars? We see the desert in the sunlight where the sand particles are carried in the wind. Guzmán says the Indian fortress and hills become one: a further metaphor that can be read as the present and the past merging and becoming one. Again we see the desert and the newer telescopes. The image is there but it is not without Guzmán's interpretation. This is followed by the scene when the sky is rotating. When Guzmán's voiceover commentary is not present, there is always music. The astral vistas are never without the touch of the music to remind us that life and time are precious.

Nostalgia for the Light is almost like reading a good novel. Each sequence is like a chapter that is connecting to the other but each of them is beautiful on its own, letting us to share the experience of the writer/director. As if Guzmán is taking us to a journey with him that he is not sure where the road is leading but has a good intuition about. In the beginning he is not sure how Atacama Desert will be both a graveyard and a gateway to the truth.

We first meet astronomer Gaspar Galaz who is a great interviewee because even though he is a scientist, he knows how to put the scientific concepts into everyday words. He wonders where we came from and where we are going. He tells in a very poetic and clear way that in science "You try to answer two questions and four more arise." And he adds "Everything we perceive is in the past, even if it's a matter of a millionth of a second." We hear Guzmán asking him "The present is a fine line?" (Supported visually with the side view of our galaxy looking a line) and Gaspar says "A puff of air would destroy it." Another important point Gaspar makes is regarding the time needed for the light to reach Earth or the light reflected by a camera lens or an eye taking some moments to 
reach us. This subject is much related to the argument that Guzmán tries to make throughout the movie. The present does not exist. It is a lapse in time and we are used to living under the influence of the past. The only possible present is the one we have in our minds. Even that is not absolute present since it takes time for the signals to travel between our senses. The present is the moment that is the accumulation of all the past moments. It is never independent of the past. As if Guzmán wants to address that time is relative, the images, the music and the pace of the movie is quite slow and smooth until here. With the help of the angle of the camera and framing (not too close or too distant - as if he is sitting just across us) we feel that we can communicate with Gaspar. His eye line is on the same level of our eye line. The camera's proximity to Gaspar is as if we are sitting right across him. Throughout the whole movie we can see that Guzmán did not push his interviewees and they gave very intimate answers. His placement is not as an authoritative figure but rather as a mediator. He is a ventriloquist reconstructing the local historical world and the opinions about it.

Gaspar's interview is sometimes cut by the images of the desert and the sky at night or the telescopes. At one point there is a shift to the rock cravings in the desert and we hear Guzmán's voiceover commentary. Then we see Gaspar again. Guzmán asks only a couple of questions to Gaspar that we actually hear him asking in the movie. One of the questions leads to the fact that archaeologists, historians and geologist all study the past but not the same past. A small link between archaeology and astronomy is made here. Like building a toy house from the Lego parts, the director is building an argument step by step with the help of editing and his interviewees.

The Atacama Desert is described as a place that allows access to the past as the it is very dry so that the astronomers can look for light that has traveled millions of years and the archeologists can look at the past and the very past ('reciben pasado y los pasados de todos, mas pasados') Our origins are either up in the sky or deeply rooted below our feet. This point is made several times in the movie.

Guzmán and Gaspar are similar in many ways. Both are actually artists following their intuition, and looking for things without any certainty. I argue that Guzmán's choice for including scientists' opinions in this film is not only because he wants to give the audience evidence but also because he values science when it can be intuitive, artistic and humanistic rather than being only positivist. (I will elaborate more on this later in this paper.)

Then we meet the archaeologist Lautaro Núñez Atencio. He is first seen driving his car in the desert and observing some stones commenting on the carvings. He narrates the collective guilt of hiding away from history by telling us about the distinct indigenous people, and the Nomadic (erante), the rock carvings, the mummies and the Columbian shepherds. He is one of the scientists in the movie who symbolizes scientific rationality and provides key facts. With the help of his narration we learn that there is more to Atacama Desert and to the past than the facts on the surface. We need to dig deeper. Not also metaphorically but also 
literally. The director interprets reality in a way that his materials and subjects in the movie offer us not only metaphorical but also literal meanings. And we are free in our interpretation.

Lautaro continues his interview by that the astronomers brought the origins of everything and the past of everything we are today. They receive the past today and the most distant past of all. His words are also intercut with the images of the space. Gaspar and Lautaro's narrations are shown one after the other. Gaspar thinks they manipulate the past just like the archaeologists. Lautaro agrees: "They study one past, we study another." They try to reconstruct a past. They are in the present recording a past. Yet these scientists are not in the same scene, and not even in the same room. According to the interviews made with Guzmán, he writes a script before he starts making a movie, and when he repeats it, it is never the same. He never tells his subjects to say what he wants them to say though he finds the right people who can talk like Guzmán's invented dialogues or monologues. This was a point that I made earlier in this paper and which I would like to explain in more depth here: When Guzmán wanted to make a movie about the women looking for the corpses of their sons and brothers, he must have understood that the Atacama Desert shared by the many including the scientists and the nomads and the ancient people is like a small Chile with paradoxes. He must have seen the comparisons and the links. After finding the right people, he has a narrative.

The next images in the film are of the carvings of the shepherds then an image of the space. Lautaro is the one to mention that the past is more accessible than anywhere else. Here we hear Guzmán's voice, it is one of the few times that he makes a point while he is interviewing someone in the movie: "And yet this country has not considered its past". This little comment does not make him an authoritative director. (He usually does not interrupt his subjects and apparently he sometimes operates the camera himself.) He is just exchanging his thoughts with Lautaro. I evaluate that this is an interactive documentary since after Guzmán says "And yet this country has not considered its past". Lautaro smiles and takes a moment to take a sip from his tea, then tells him that this paradox concerns Guzmán most. Lautaro knows what Guzmán wants to point out. He says he agrees with him. Lautaro's eye level is also on our eye level. The place where he looks at looks as if he is looking into our eyes. At one point I even thought he was looking into the camera. His words are intercut with the photos from $19^{\text {th }}$ century of some construction (probably the construction of the observatories) and workers. Lautaro talks about the marginalized Indians. These photographs do not represent misery though. At least on the surface... This is also the moment when Lautaro clearly mentions politics and that the past have been concealed.

In the next scene we see a graveyard with wooden crosses, and coffins, some full of old and torn boots and clothes, and bones. It is a huge graveyard for the lost people of the nomadic families. The next images are of the Chacabuco concentration camp, a broken light bulb, dusty spoons and other objects such as boots, bottles, books, and some archival stills. The tinkling sounds of the spoons 
every time the wind blows prompts us to think that this place was not totally silent some time ago. Cut to the image of (probably) Gaspar observing the space at night. Then we see an archival footage of the camp. In the voiceover commentary it is stated that the military did not have to build a camp since they used the old saltpeter mines from a time mining industry was like slavery. All the military had to do was to add barbed wire. And the Pinochet junta dumped the remains of the oppressed indigenous people here in the desert. Then we hear the story of Luís Henriquez, who survived the camp. We do not see his face first but we see the concentration camp as if Guzmán wants to point out that the story of the whole imprisoned people is more important than the story of Luís. We hear the stories about the cells, Pinochet's dictatorshop and the telescopes. This is one of the interviews in the movie that we hear Guzmán's questions and comments the most. One of the reasons of this is that the two previous interviewees do not give evidence from their personal history. They are scientists who give facts and opinions about the work that they do whereas Luís is a witness, and we would like to hear about the background to his story therefore we need to hear the questions that are asked to him. The scientists represent the hope and the class differences as well as they serve as the solid examples of the conscience of the Chilean society. Their remarks are to support the need of Chile to come to terms with its past.

Luís looks at a map and draws a tripod with a dial on top before we see his face. These are his evidences too. Suddenly his personal history is linked with facts. Facts those are almost objective as the scientific ones. The built and ready to use version of the machine he draws is also shown in the movie. This way we can imagine how the past might have been. Luís tells that the sky was so transparent, and that they felt free while observing the space but the astronomy lessons were cancelled since the military was afraid that they might escape. He also reads out the names of his comrades whose names almost vanished from the wall which is falling apart. Guzmán comments: "He remembers traces that are erased. He is transmitter of history." Just like the other witnesses in the movie, Luís is the representative of the power of the memory. He still knows all of his friends' names by heart, and can draw the machine that they used to build. His dignity lies in his memory. The names can erase from a wall or the traces of cables and watchtowers maybe gone forever but they can stay in one's memory. We do not see Luís in the most usual interviewee position where one is usually seated. This must be a choice of the filmmaker to show Luís freely walking, drawing, presenting and telling rather than sitting across the camera and answering some questions. Luís as the symbol of dignity is last shown looking at the sky superimposed with the image of floating dust particles. He is connected with the past.

The dust particles do not exit the screen even when we meet the architect Miguel Lawner who was in exile too though he mostly narrates the story of the prisoners in the concentration camps. He tells that he made the drawings of the cells and the camp by measuring every single place by his feet. He actually measures a room in his house by his feet and then explains to Guzmán that he 
measured the camps the same way. Miguel's other evidence are the pictures he drew before and those he draws during the filming. His evidence is partially personal and partially objective. When we see the remains of the camp, him measuring the rooms in his house, his confident points about his memory, we know that he is telling the truth. He is the only interviewee who talks about his own memory and says how he remembered the concentration camp, and that the architects are good at remembering dimensions. It is no wonder that he remembers. Only to the end of the interview with Miguel, Guzmán reveals that Miguel's wife has Alzheimer's and he sees Miguel and his wife as a metaphor of Chile: remembering and forgetting. This narration is supported by the image of Miguel and his wife walking slowly. We see them from behind. A distant past and a present that is becoming the past are walking away. One cannot stop the time.

We then meet Victor González who is a young astronomer and an "hijo de exil" (child of exile). He is different than the other scientists in the movie. Unlike Gaspar and Lautaro he does not really narrate the key facts that lead the story to develop but in fact he is the representation of the future. A future where the past has been considered and peace has been made. .. Victor says he is not from anywhere but he feels Chilean. He actually is the one who mentions the future too. His role in the movie makes much more sense when we see him with his mother in their kitchen. While preparing a meal, cutting some vegetables, his mother tells Victor that it is very difficult for the families who lost their loved ones because they cross paths with the torturers on the street and it traumatizes them again. This is the difference between the searches of the scientists and the "Mother of the Disappeared" even both of them work in the past. This scene is so valuable that even on its own it reveals so much of the past. Victor's mother is not interviewed by Guzmán since his choice in the film is not to show the total misery and the trauma but yet emphasize the metaphors. (Next we see women with shovels looking for bones and other things that might be left from their relatives in the desert.) In the same way, in the later scenes Gaspar says that even if the searches of the Mothers of the Disappeared and theirs are similar, they can sleep peacefully but these women cannot. The women trace the remains of their loved ones but the astronomers trace the space with joy. Gaspar also emphasizes that the society has greater understanding for astronomers than these women and he is very sorry that it is so.

From the voiceover commentary, we learn that during the filming the body of a female prisoner was found. In the following scene Gaspar says that if his parents were lost, he would imagine they were somewhere in the galaxy. Cut to Lautaro. He mentions the women who are relatives of the lost people helped them find the tiny bones, fragments of skulls and the other human remains.

It is time to meet one of the women who is searching for her brother: Vicky Saavedra. We do not meet Vicky until we learn the background to the subject. We see some small stone-like objects in her hands. She tells us that they are particles of bones, and explains which part of the body they might belong. Then she tells us 
she found the remains of her brother's body, and that he was shot. She too has evidence and is shown with the evidence. Just like the other subjects in the movie, she is shown in her natural, everyday look. She sits on the ground of the desert while she is talking. She looks very sad but strong. She is willing to share her story with us. She does not seem she is forced. At those moments she is on the screen, we share her grief. Her memory is so vivid. Then we see her brother's photo. She tells us that she found the foot of her brother, and spent a whole morning with it. She felt united with her brother, and it was a great joy and disappointment.

These scenes are succeeded by Lautaro explaining the audience what he knows about the victims of Calama. His words are intercut with the still images of the archaeologists and the human remains. "It is up to the military to give information so that these lost people can be buried properly."

The next subject we meet is Violeta Berríos. She sits on the ground, talking slowly as if she is still living the moment when she lost her son. She says she will continue searching no matter what. She does not believe that the bodies were thrown into the sea, and just because of the misinformation or the lack of information she feels like an idiot. And yet she does not lose her strength and hope. She and Vicky go to the desert with hope every day and leave with their heads hanging but they shake themselves and go there with more hope the next day. She tells Guzmán that she wants to find them whole, and that she is not alone. Her memory is as vivid as Vicky's. She cries saying that she does not want to die without finding them. She wishes the telescopes could also see through the earth, and thanks the stars for helping them finding their relatives.

We see Gaspar again. He is at the observatory. An American scientist called George Preston and Gaspar explain to us what the image on the monitor are: It is a digital imprint of a star, and there are calcium lines. George remarks calcium in our bones were made right after the Big Bang.

Cut to Lautaro. He says he would never be able to forget if his son were killed in any dictatorship no matter which and no matter what sort of a social class he belonged to. He emphasizes the fact that we are morally obliged to preserve our memory.

Cut to a footage of the Pisagua Mass Grave of 1990. Lautaro says we have to continue our search. And he is hopeful too. Cut to grave and bodies again.

The camera shifts to Violeta. She drinks water. She needs more strength to tell her story. Her memory is very vivid too. She expresses that it is better for the society that they are less and less. (We learn earlier in the movie that some women stopped searching in 2002). It means fewer problems for the society or the government. "Because we are a problem. For society, for justice, for everyone... We're the lowest of the low. We are the leprosy of Chile." These women not only long for their relatives but they also have to face the strange gazes of the people and disrespect. Their past is haunting them. Not their personal past but the past that they were forced to have because of the junta. Their present is never without their heartbreaking past, and some memories cannot be erased. 
Cut to archival stills of the women looking for their loved ones accompanied by music. The transition between these photos is faster than the overall pace of the movie. A sign reads "no fue la guerra, fue matanza" (it was not a war, it was a massacre.) Cut to the group of women all together then cut to the domes of observatory. Before the movie these women's way never cut with that of the astronomers. Guzmán accomplishes a great association between all the stories and the images.

Guzmán informs us that the ancient people also knew about the stars and that the scientists saved the antiquity and keep them in boxes. Here a scientist shows us a mummy. Later Guzmán describes one of his memories from his childhood about the museum and the skeleton of a whale which still is in the same museum. He emphasizes that the stars and human have something is common which is the calcium. This is the second time that calcium and star-dust are mentioned in the movie. Guzmán seems to show us that the whole past is a whole. Then he articulates the fact that the treasures/bodies/objects of the antiquity that the scientists keep in boxes do not have any names. He wonders whether they will be placed in a monument or be given a burial. Other than the stories and the remains of the lost people, we do not see a total evidence of the massacre but indirectly the remains of the ancient people, the mummies represent the massacre. By asking whether the mummies will be given a burial, he actually wonders whether the lost people will be given a proper burial.

Cut to Vicky looking for the remains of her brother in the desert. Then we are introduced another dictatorship survivor who is very candid as well: Valentina Rodriguez is also an astronomer. Her voice overlaps with the images of her grandparents sitting silently on a couch. They both look peaceful but somehow sad. Valentina's image is cut to her grandparents pictures several times. Valentina talks about the cycle of life, her personal memory, astronomy, pain, loss and absence. She says astronomy helped her overcome her pain at times:

Astronomy has somehow helped me to give another dimension to the pain, to the absence, to the loss. Sometimes when one is alone with that pain ... the pain becomes oppressive. I tell myself it is all part of a cycle that didn't begin and won't end with me, nor with my parents, or with my children (tal vez). I tell myself we are all part of a current -of an energyof recyclable matter. Like the stars which must die that other stars cam be born, other planets, no life. In this context, what happened to my parents and their absence takes on another dimension. It takes on another meaning and it frees me a little from this great suffering as I feel that nothing really comes to an end.

The image is cut with the images of the spanning galaxies. We still hear Valentina talking. We are shown the childhood images of hers, images of her parents and grandparents. Cut to Valentina holding her baby. This scene is followed by the photos of the lost people - very old photos. Some are torn or the 
colors are fading. As if the memories of the victims also fade from earth. The scene is supported with music and the bird sounds. This scene reminded me of the scene in the beginning of the movie where we see an example of provincial life. Both scenes are cast in half shadow and half-light, and the leaves are moving due to the wind. These scenes are visually and emotionally similar. We see that the memory can be alive even the material presence is fading from the world. Valentina says: "I'm a product with a manufacturing defect which is invisible... I realize that my children don't have this defect, nor does my husband and that makes me happy". Valentina and her baby boy serve as the symbols of hope, future, and the cycle of life.

We see the telescope again. When the top of telescope is opening there is no music but when Gaspar, Violeta and Vicky enter the image, the music starts. Science without humanism is not good. We do not hear them talking. Both Violeta and Vicky are smiling. We see Violeta smile for the first time in the movie. The dust particles and the women's image are superimposed. The educated and young scientist and the elderly women who are not educated gather which is very beautiful. Guzmán then shows us some wonderful marbles which he found that were like the ones from his innocent childhood. He says Chile's problems seem insignificant compared to the vastness of the cosmos but when you put them on the table they are like a galaxy, and as kids, each of them would carry the entire universe in their pockets because the people and their problems are like marbles and the universe.

We then see Santiago at night. Contrary to the desert full of the past and the victimhood, Santiago is full of buildings and lights. Guzmán makes his final point: "Memory is constantly attracting us. Those who have the memory live in the past, those who do not, do not live anywhere." What Guzmán wants to draw attention to is that we should not forget the past but come to terms with it for an emotionally healthy and free future.

\section{Science and Positivism}

Some scholars might calls Nostalgia for the Light a docudrama and some an essay documentary. I would like to call it a "documemory" since there is already an organic tie between documentary and history. I find Nostalgia for the Light very hybrid. The word does not even exist yet Nostalgia for the Light seems to be a combination of documentary techniques and memory. It is like literature, and it has a structure. All the subjects and the images seem to have an importance of their own independent of each other and yet they form a whole. They all add to the story; a lyrical and deeply moving story which is like meditation, which raises awareness without making its subjects look weak. The collective loss becomes a part of our memories too. I believe that Guzmán wants history and memory in Chile to overlay to create a popular memory. That is why I call Nostalgia for the Light a documentary because it is an overlay of a documentary and memory. It is not a historical documentary. 
He uses science as a way of finding answers to questions but his work is not scientific or objective. It is an aesthetic work with intuitive and subjective ideas, partial evidence. And yet the evidence he demonstrates to us creates a shared experience. It stimulates discussion about the topic.

Guzmán also uses repetition of images to emphasize his point that life is cycle so is history. In the eternal cycle things repeat. Just as in the old Chile people were killed. In the modern times the junta killed people too. To make this cycle stop, it is essential to first accept the truth and take some lessons, and to find the equilibrium. He uses several conventional, simple and direct ways of documentary film making but he uses them in a way that makes the movie atypical. Almost like meditation. He borrows from journalism, takes some things from literature. In end of the day, he can associate all the materials that his intuition led him to discover.

Most of us watch documentaries with the expectation of learning. When it is sometimes impossible to comprehend the whole world in front of our bare eyes, imagine how difficult it is to see the whole truth through a lens. We expect not to be tricked or lied to. And yet Guzmán never gives up honoring science and evidence. The interviewees are there to give evidence, they give testimonies which are not completely provable yet we know that we are not tricked. The emotions of both the scientists and the women are sincere and we feel it. Their testimonies are also supported with evidence such as bones, photos, camps etc. Since the past is reconstructed in the minds of the people, he knows that memory is subjective and the moments about his childhood in the movie are limited. Therefore the stories of the victims are private but not personal. Guzmán's perspective is quite fresh, it is authentic. He pairs the scientific history and the political history. His interviewees are chosen among experts and witnesses yet not politicians or military people because this documentary is not about them. It is about the victims and their peace. Guzmán takes responsibility in raising awareness about the topic but he does it so well by not separating the problems. He knows where his responsibility towards the issue starts and ends.

Guzmán chooses a method where we can enjoy the informing aspects of a documentary with the help of testimonies, representations (in this case not reenactments but objects that resemble the pieces of the problem of torture here) and symbols such as the Atacama Desert (a purgatory like place that stands as emblematic of the violence). His method also permits the audience to follow the journey of the filmmaker and the victims, form a memory of the gender and class violence as a crime against humanity in their minds. The audience still has room for imagination and making the connections between the stories on his own. The evidence is there just to help them build their own ideas about the story. The evidence is inconclusive and intangible but the movie is not incomplete. And the evidence in the movie cannot mostly be witnessed as it happens except for a couple of moments such as Luís drawing the telescope and Miguel drawing the concentration camp. 
Guzmán wants to put an end to the cultural amnesia with the help of this movie but he knows that it is just the beginning and this is just a movie.

\section{REFERENCES}

James Monaco. How to Read A AFilm. New York: Oxford University Press, 2004. 